Dicle Üniversitesi

Ziya Gökalp Eğitim Fakültesi Dergisi
Dicle University

Journal of Ziya Gökalp Faculty of Education

\title{
Ortaokul Matematik Ders Kitaplarında Sosyal Değerler
}

\section{Ömer ŞAHİN ${ }^{1}$, Murat BAŞGÜL²}

${ }^{1}$ Dr. Öğr. Üyesi, Amasya Üniversitesi, mersabin60@gmail.com

2 Araş.Gör., Amasya Üniversitesi, muratbasgul60@gmail.com

Geliş Tarihi/Received: 15.03.2018～Kabul Tarihi/Accepted: 06.06.2018ｅ-Yayım/e-Printed: 11.01.2019

DOI: $\underline{\text { http://dx.doi.org/10.14582/DUZGEF.1890 }}$

ÖZ

Bu çalışmanın amacı ortaokul matematik ders kitaplarında yer alan sosyal değerlerin incelenmesidir. Araştırmanın amacı doğrultusunda nitel araştırma yöntemlerinden birisi olan durum çalışması kullanılmıştır. Bu çalışmanın veri toplama sürecinde nitel veri toplama tekniklerinden doküman incelemesi yöntemi tercih edilmiştir. Bu bağlamda bu çalş̧mada veri toplama sürecinde Milli Eğitim Bakanllğının öğretmenlere elektronik doküman sağlayan wnvw.eba.gov.tr sitesinde yer verilen matematik ders kitapları incelenmiștir. Ders kitaplarında yer alan sosyal değerlerin analiz edilmesinde nitel veri analiz tekniklerinden betimsel analiz tekniği kullanılmıştır. Çalışmada kullanılacak sosyal değerlerin belirlenmesi için literatürde yer alan sosyal değerlere ait sinıflandırmalardan (Haydon, 2006; Nelson, 1974; Rokeach, 1973; Schwartz, 1992; Spranger, 1928; Sennett, 2003; Tillman, 2000) bir çatı oluşturulmuştur. Bu araştırmanın çatısı; sevgi, sayg1, sorumluluk, yardımlaşma, hoşgörü, iyilikseverlik, evrenselcilik ve nezaket sosyal değerlerinden oluşmaktadır. Çalışa sonucunda; en fazla sosyal değere yedinci sınıf ders kitabında yer verilirken, en az sosyal değere ise altıncı sinıf ders kitabında yer verildiği görülmüştür. Ders kitapları genel olarak değerlendirildiğinde ise; ders kitaplarında en fazla sorumluluk değerine yer verilirken, en az hoşgörü değerine yer verildiği tespit edilmiştir. Ayrıca sekizinci sınıf ders kitabı hariç diğer kitaplarda; en fazla sosyal değere Saynlar ve İşlemler öğrenme alanında yer verilmektedir.

Anahtar Kelimeler: Matematik, ders kitabı, sosyal değerler

\section{Social Values in the Middle School Mathematics Textbooks}

\begin{abstract}
The purpose of this study is to examine the social values in secondary school mathematics textbooks. The case study method, one of the qualitative research methods, was used to examine the social values in the textbooks. In this study, documents and artifact collection method, one of the qualitative data collection techniques, was used in the data collection process. In this context, mathematics text books were examined which are located in www.eba.gov.tr. The Ministry of National Education provides electronic documents to the teachers in EBA. Descriptive analysis technique, one of the qualitative data analysis techniques, was used to analyze social values in the textbooks. A framework was composed from the classification of social values in the literature to determine which one of the social values must be used (Haydon, 2006; Nelson, 1974; Rokeach, 1973; Schwartz, 1992; Spranger, 1928; Sennett, 2003; Tillman, 2000). The framework of this research consists of social values such as love, respect, responsibility, cooperation, tolerance, benevolence, universalism and courtesy. At the end of the study; the most social value is given in the seventh grade textbook, while the least social value is in the sixth grade textbook. The most common values in the mathematics text books were found as responsibility value. The least common values were observed as tolerance value. In addition, except for the eighth grade textbook; the most social values are taken place in the "Numbers and Operations" learning domain.
\end{abstract}

Keywords: Mathematics, textbook, social values

\section{GİRİ̧̧}

Eğitim tarihinin başlanıcından beri değerler, eğitimin ayrılmaz bir parçası olarak varlığını sürdürmüştür. Eğitimin en önemli amacı daha nitelikli ve daha iyi insan yetiştirmektir. Burada değerlerin önemi ön plana çıkmaktadır. Güngör (1993) değerleri "bir şeyin arzu edilebilir veya edilemez olduğu hakkındaki inançlar" olarak tanımlamaktadır. Rokeach (1973), değerleri bireyin veya toplumun davranışlarının ve bu davranışların sonuçlarının kabul edilebilir olup olmadığını denetleyen inançlar olarak tanımlamaktadır (akt. Lyons, 2003). Farklı yaşantılar sonucu elde edilen değerler insan davranışına yön veren rehberlerdir (Raths, Harmin ve Simon, 1978). Değerler, algılar ve tutumlar için belirleyici bir çerçeve olmasıyla kişinin davranışlarını doğrudan ve dolaylı olarak yönlendirmektedir (Güngör, 1993). Aynı şekilde Kuşdil ve Kağıtçıbaşı (2000), değerlerin bireyin davranışlarını açıklamada kritik bir öneme sahip olduğu ifade etmektedir. Değerler toplumları, grupları ve bireyleri tanımlayarak davranış ve tutumlarına yön veren yapılar olmalarıyla psikoloji, sosyoloji ve antropoloji gibi disiplinlerin odak noktası olmuştur (Schwartz, 2012). 
Değerlerle ilgili birçok yaklaşım ortaya koyulmuştur. Bunlardan biri Spranger yaklaşımıdır. Spranger değerleri; bilimsel, ekonomik, sosyal, politik, dini ve estetik değerler olarak sınıflandırmış ve bireysel özellikleri bu sınıflandırmadan faydalanarak gruplandırmıştır (akt. Güngör, 1993). Schwartz (2012) değerleri; öz-yönetim, başarı, hazcılık-zevk, güç, uyma, güvenlik, geleneksellik, harekete geçme, yardımseverlik, evrenselcilik şeklinde sınıflandırmıştır. Rokeach (akt. Lyons, 2003) değerleri amaç ve araç değerler olarak sınıflandırmıştır. Cohen (1985'den akt: Akbaba Altun, 2003) değerleri içsel, dışsal, ahlaki, kişisel ve bilgiye dayalı değerler olarak kategorize etmiştir. Değerlerle ilgili olarak bu sınıflandırmalar geçmişten günümüze yapılan birçok çalışmaya rehberlik etmiştir.

Değerler toplumdan bağımsız düşünülemeyeceği gibi değerlerin geliştirilmesinde toplumsal normlar, kültür ve inançlar kritik önem taşır (Akbaba Altun, 2003). Değerler toplumdaki bireyler tarafindan içselleştirilip kabul edildiğinde zaman içinde gelecek nesle aktarılır ve devamlılığ1 sağlanır (Gudmunsdottir, 1991). Toplumların varlığını sağlıklı bir şekilde sürdürebilmeleri için değerlerini yeni kuşaklara aktarması gerekmektedir (Dilmaç \& Ekşi, 2007). Değerlerin bireylere kazandırılması değerler eğitimi yoluyla gerçekleşmektedir. Değerler eğitimi ile sosyal, siyasal, kültürel ve estetik değerlerin kazandırılması amaçlanmaktadır (Veugelers \& Vedder, 2003). Değer eğitimi bireylerin ait oldukları toplumun değerlerini kazanmalarını sağlayarak onları daha kaliteli ve tatmin edici bir yaşam kurmalarına yardımcı olur (Kirschenbaum, 1995). Değerler eğitiminin amac1 bireylere sevgi, sayg1, sorumluluk, hoşgörü, adalet gibi değerlerin kazandırılmasını ve bu değerler arasında bütüncül bir ilişki ortaya konulmasını sağlamaktır. Bireyler kazandıkları değerleri olgu ve olaylar karşısında birer ölçüt olarak kullanmaktadır (Kıncal, 2007). Toplumlarda demokrasi kavramının gelişebilmesinde değerler eğitiminin önemli bir rol oynamaktadır. Değerler eğitiminin önemi geçmişten günümüze artarak devam etmektedir. Dünya genelinde yaşanan ahlaki sorunlar ve artan suç oranları değerler eğitiminin kritik önemini ortaya koymaktadır (Lickona, 2009).

Aileler çocuklarının ahlaki eğitiminde en önemli yere sahipken, ailenin ardından okul toplumsal değerleri kazandıran bir kurumdur. Değerler disiplin sınırlaması olmaksızın, sınıf içindeki öğrenme ortamının organize edilişinde, eğitim ve öğretim etkinliklerinde, içerik tercihinde, hedef ve kazanımlarda, disiplin kurallarında ve öğrencilere yönelik yaklaşım ve tutumlarda yer almaktadır (Veugelers \& Vedder, 2003). Öğretmenler bu süreçte bilinçli ya da bilinçsiz olarak değerleri öğrencilerine kazandırırlar (Coombs-Richardson \& Tolson, 2005). Çocukların zamanlarının büyük kısmını okulda geçirdikleri için okullar değer eğitiminde önemli bir pozisyon üstlenmektedir (Erden, 1998). Değerlere yönelik kazanımlar okul öncesi dönemde başlar ve bireyin yaşamı boyunca şekillenmeye devam etmektedir. (Balat Uyanık ve Dağal Balaban, 2006). Özellikle ilköğretim seviyesindeki çocuklar toplumsal olaylar ve olgularla ilgili bakış açısı kazanmakta bu nedenle doğru bakış açısı kazanmaları ve doğru yönde yönlendirilmeleri gerekmektedir (Can, 2002; MacIntyre, 2000).

Değerlerin öğrencilere kazandırılmasında etkili bir öğretim programın hazırlanmasının önemi büyüktür (Yazıc1, 2006). Akbaş (2008)' a göre değerler öğretim programları aracıllı̆̆yla doğrudan ve dolaylı olarak öğrencilere kazandırılabilir. Kirschenbaum (1995) da temel değerlerin öğrencilere kazandırılmasında öğretim programlarının rolünü vurgulamıştır. İlkokul matematik öğretim programları incelendiğinde 2009 ve 2015 programlarında değerler yer almazken 2017 programında değerler için ayrı bir bölümde adalet, paylaşım, bilimsellik, esneklik, eşitlike, özgürlük, sabır, saygg, sorumluluk ve tasarruf olmak üzere 10 adet değere yer verilmiştir (Baş, 2017). Öğretim programlarının hedeflerini gerçekleştirmede kullanılan en önemli araçlardan birisi ders kitaplarıdır. Bundan dolayı ders kitapları öğrencilere değerleri kazandırma sürecinde önemli bir rol oynamaktadır (Sanchez, 1998; Gül, 2017). Ait olduğu dönemin toplumsal ve siyasi yapısını yansitan (Tüfekçioğlu, 1997) ders kitapları içeriğiyle öğrencilere bilgi aktarımının yanı sıra içinde yaşadıkları toplumun değerlerini kazandırabilme özelliğine sahip olmalıdır (Tanrı̈ver, 2003; Körükçü, Kapıkıran \& Aral, 2016). Yine Milli Eğitim Bakanlı̆̆1 mevzuatında ders kitaplarıly ilgili olarak "Öğretim programının kazandırmayı amaçladı̆g değer, tutum ve yeterlikleri kapsar. Türk toplumunun sosyal, ablaki, kültürel ve tarihî değerlerini gelistirerek yasatır." (MEB, 2007) ifadeleri yer almaktadır. Alanyazına bakıldığında değerlerle ilgili çalışmaların diğer disiplinlere nazaran 
matematik dersi açısından daha az sayıda olduğu görülmekte, bunun nedeninin ise matematiğin değer taşımayan bir alan olarak algılanıyor olduğu düşünülmektedir (Dede, 2007). Bishop (1999) matematik eğitimi ve değerlerle ilgili çalısmasında matematiğin ve değerlerin ilisskisiz olduğunu düşünmenin yanlış olduğunu ve değer eğitiminin matematik eğitiminde önemli bir yeri olduğunu vurgulamışır. Bu nedenle ortaokul matematik ders kitaplarının sosyal değerler açısından incelenmesinin hedeflendiği bu çalışmaya ihtiyaç duyulmuştur. Sosyal değerler toplumun fertlerini birbirine yaklaştıran, bir arada tutan, toplumun devamını sağlayan temel yargılar, değerler olarak tanımlanmaktadır (TDK, 2018). Sosyal değerler, "neyin doğru, neyin yanlış, neyin iyi, neyin kötü, neyin güzel, neyin çirkin, neyin adil olduğu konusunda genel yargilara varma olanağ1 tanırlar. Toplum yaşamında hemen her şey, bu değerlere göre algılanır. Böylelikle bireyler yaşamın anlamını öğrenirler.” (Güven, 1999). Bu tanımlardan sosyal değerlerin sağlıklı kararlar alabilen, kendini toplumun bir parçası olarak görerek sosyalleşebilen bireyler yetiştirilebilmesi açısından önemli olduğu anlaşılmaktadır. Spranger (2001)' e göre bireylerin empati kurabilme, birbirini sevebilme, affedebilme ve fedakarlıkta bulunma gibi erdemlere sahip olması ve toplum çıkarlarını ön planda tutan bir anlayış kazanabilmesi için sosyal değerlere sahip olması gerekmektedir.

Bunlara ek olarak, ilgili literatürde bu çalışmaya benzer bir şekilde matematik ders kitaplarında yer alan sosyal değerlerin incelenmesine yönelik bir çalışmaya rastlanmamıştır. Fakat ilgili literatürde yer alan çalışmaların (Izgar, 2013; İnan Kılç, 2009; Özkan, 2010; Sezer, 2005; Turan, 2010; Varol, 2013) daha çok sosyal bilgiler, hayat bilgisi, din kültürü ve Türkçe gibi disiplinlerde yoğunlaştı̆ğ görülmektedir. Matematik ders kitapları üzerine yapılan çalışmalarda (Dede, 2006a; Dede, 2006b; Seah \& Bishop, 2000) ise genel olarak matematiksel değerlerin ve matematik eğitimi değerlerinin incelendiği görülmüştür. Bu çalışmada matematik eğitimi değerleri yerine sosyal değerler üzerinde durulması bu çalışmayı diğer çalışmalardan ayıran yönlerinden birisidir. Bu çalışmayla matematikte eğitiminde değerler eğitiminin matematik değerleriyle sınırlı olmadığ1 2017 öğretim programında yer bulan (Baş, 2017) sabır, sayg1, sorumluluk gibi sosyal değerlerin de matematik eğitiminde yer bulabileceğinin vurgulanması amaçlanmıştır. Bu nedenle beşinci, altıncı, yedinci ve sekizinci sınıf matematik dersi kitaplarının sosyal değerler açısından incelenmesinin hedeflendiği bu çalışmaya ihtiyaç duyulmuştur. Bu bağlamda bu çalışmada ortaokul matematik ders kitaplarında sosyal değerlere nasıl yer verildiğinin belirlenmesi amaçlanmıştır. Araştırmanın amacı doğrultusunda matematik ders kitaplarında sınıf düzeyine ve öğrenme alanlarına göre sosyal değerlere nasıl yer verildiği incelenmiştir.

\section{YÖNTEM}

Çalısmanın bu bölümünde, araştırmanın yöntemi, verilerin toplanması ve verilerin analiz süreçlerine yer verilmiştir.

\subsection{Araştırmanın Deseni}

$\mathrm{Bu}$ araştırmada ortaokul ders kitaplarında yer alan sosyal değerleri incelemek amacıyla nitel araştırma yöntemlerinden birisi olan durum çalısması kullanılmıştır. Durum çalışması yönteminde; bir olay, durum, ilişki veya süreç sınırlı sayıda örneklem yardımıyla derinlemesine incelenir (Denscombe, 2010). Durum çalışması yönteminde yer alan durumlar; kişiler, kitaplar, öğretim programları, gruplar (topluluklar), davranışlar veya olaylar olabilir (Creswell, 2011; Neuman, 2014; Yin, 2011). Bu çalışmanın durumunu ise araştırmanın amacı doğrultusunda matematik ders kitaplarında yer alan sosyal değerler oluşturmaktadır.

\subsection{Verilerin Toplanmas1}

Bu çalışmanın veri toplama sürecinde nitel veri toplama tekniklerinden doküman incelemesi (documents and artifact collection method) yöntemi tercih edilmiştir. Çünkü dokümanlar nitel araştırmalarda kullanılan önemli bilgi kaynaklarından birisidir (Yıldırım \& Şimşek, 2011). Doküman incelemesi yönteminde, araştırmanın amacı doğrultusunda veri elde edilmesini sağlayan yazılı, sözlü ve görsel materyaller kullanılabilir (McMillian \& Schumacher, 2010; Yıldırım \& Şimşek, 2011). Bu bağlamda bu çalışmada veri toplama sürecinde Milli Eğitim Bakanlı̆̆ı'nın öğretmenlere elektronik doküman sağlayan wmw.eba.gov.tr sitesinde yer verilen ortaokul matematik ders kitapları incelenmiştir. Bu çalışmada sosyal değerler açısından incelenen ders 
kitaplarına "incelenen ders kitapları" başlı̆̆ı alıında çalışmanın kaynakçasında yer verilmiştir. Ayrıca bu çalışmada incelenen matematik ders kitapları her sınıf düzeyi için farklı yayın evleri tarafından hazırlanmıştır.

\subsection{Geçerlik-Güvenirlik}

Aşağıda yer Tablo 1' de araştırmanın geçerlik ve güvenirliğini sağlamak için yapılan işlemlere yer verilmiştir.

Tablo 1. Araştırmanın nitel kısmının geçerlik-güvenirliğine yönelik yapılan işlemler

\begin{tabular}{cl}
\hline Geçerlik & Literatür taraması, amaçsal örnekleme, doğrudan alıntılar (ayrıntılı betimleme). \\
\hline Güvenirlik & $\begin{array}{l}\text { Kavramsal çerçeveye bağlı olarak yapılan veri analizi, kodlama güvenirlik yüzde } \\
\text { hesabı. }\end{array}$ \\
\hline
\end{tabular}

$\mathrm{Bu}$ çalışmada araştırmanın geçerliğini sağlamak amacıyla araştırma probleminin seçilmesinde, geliştirilmesinde ve araştırma sonunda ortaya çıkan sonuçların tartışılmasında ilgili literatürden yararlanılmıştır. Ayrıca çalışmanın geçerliğini artırmak için ders kitaplarının seçilmesinde amaçsal örnekleme yöntemi tercih edilmiştir. Bu bağlamda araştırmanın amacı doğrultusunda ortaokul matematik ders kitapları incelenmiştir. Bunlara ek olarak geçerliği artırmak için bulgular ders kitaplarından alınan doğrudan alıntılarla desteklenmiştir. Çalışmanın güvenirliğini sağlamak içinde verilerin analizinde araştırmacılar tarafından oluşturulan bir veri analiz çerçevesi kullanılmıştır. Ayrıca güvenirliği artırmak için veriler iki araştırmacı tarafından kodlanmış ve kodlama güvenirlik yüzdesi hesaplanmıştır.

\subsection{Verilerin Analizi}

Ortaokul matematik ders kitaplannda yer alan sosyal değerlerin analiz edilmesinde nitel veri analiz tekniklerinden betimsel analiz tekniği kullanılmıştır. Betimsel analiz tekniğinde araştırmacı, daha önceden geliştirilmiş temalar ve kodlar yardımıyla elde ettiği verileri analiz edebilir (Yıldırım \& Şimşek, 2011). Ayrıca betimsel analiz tekniğinin kullanıldığı çalışmalarda verilerin elde edildiği kaynaklardan (gözlem, görüşme, doküman) doğrudan alıntılara yer verilebilir. Bu çalışmada kullanılacak sosyal değerlerin belirlenmesi için literatürde yer alan sosyal değerlere ait sınıflandırmalardan (Nelson, 1974, akt; Naylor ve Diem, 1987; Rokeach, 1973; Schwartz, 1992; Spranger, 1928; Tillman, 2000) bir çatı oluşturulmuştur. Bu araştırmanın çatıs1; sevgi, sayg1, sorumluluk, yardımlaşma, hoşgörü, iyilikseverlik, evrenselcilik ve nezaket sosyal değerlerinden oluşmaktadır. Araştırmanın çatısında yer alan sosyal değerler ve bu sosyal değerlere yer veren çalışmalar aşağıda yer alan Tablo 2' de özetlenmiştir. Başka bir ifade ile bu çalışmada matematik ders kitaplarında yer alan örnekler, problemler, etkinlikler ve alıştırmalar bu araştırmanın çatısında yer alan sosyal değerler açısından incelenmiştir.

Tablo 2. Araştırmanın çatısında yer alan sosyal değerler

\begin{tabular}{ll}
\hline Değerler & Değerlere Yer Veren Calışmalar \\
\hline Sevgi & Spranger, 1928; Rokeach, 1973 \\
\hline Sayg1 & Haydon, 2006; Nelson, 1974; Rokeach, 1973; Sennett, 2003 \\
\hline Sorumluluk & Rokeach, 1973; Tillman, 2000 \\
\hline $\begin{array}{l}\text { Yardımlaşma } \\
\text { (işbirliği) }\end{array}$ & Rokeach, 1973; Schwartz, 1992; Tillman, 2000 \\
\hline Hoşgörü & Tillman, 2000 \\
\hline Iyilikseverlik & Rokeach, 1973 \\
\hline Evrenselcilik & Rokeach, 1973; Schwartz, 1992 \\
\hline Nezaket & Rokeach, 1973
\end{tabular}

Çalışmanın güvenirliğini sağlamak için ortaokul matematik ders kitapları iki araştırmacı tarafından analiz edilmiştir. Dolayısıyla birden fazla araştırmacının veri analizi yaptığı durumlarda kodlama güvenirliğinin incelenmesi gerekmektedir. Bu durumda araştırmacılar ilk olarak aynı veri setini birbirinden bağımsız olarak kodlarlar. Daha sonra yapılan kodlamaların benzerliklerini ve farklılıklarını sayısal olarak karşılaştırarak güvenirlik yüzdesi belirlenir. Bu tür çalışmalarda kodlama güvenirlik yüzdesinin en az \%70 seviyesinde olmas1 gerekmektedir (Yıldırım \& Şimşek, 2011). Bu amaçla çalışmadan elde edilen veriler iki araştırmacı tarafından kodlanmış ve kodlama güvenirlik yüzdesi \% 83 olarak bulunmuştur. Daha sonra araştırmacılar bir araya gelerek farklılaşma olan kodlamalar üzerinde uzlaşmaya vararak veri analiz süreci tamamlanmıştır. Diğer bir ifadeyle iki puanlayıcı tüm kodlamalar üzerinde uzlaşmaya vardıktan sonra veri analiz süreci tamamlanmışır. 
Aşağıda yer Tablo 3’ de araştırmanın veri analiz sürecini daha anlaşılır kılmak için örnek bir veri analiz çerçevesine yer verilmiştir.

Tablo 3. Araștırmanın veri analiz çerçevesi

\begin{tabular}{|c|c|c|c|c|c|c|}
\hline Kitapta Yer Alan İfade & $\begin{array}{l}\text { Kodlayıc1 } \\
\text { ar }\end{array}$ & $\begin{array}{l}\text { Sinif } \\
\text { Düzeyi }\end{array}$ & & $\begin{array}{l}\text { Öğrenme } \\
\text { Alanı }\end{array}$ & $\begin{array}{l}\text { Alt Öğrenme } \\
\text { Alanı }\end{array}$ & $\begin{array}{l}\text { Sosyal } \\
\text { Değerler/Göstergele } \\
r\end{array}$ \\
\hline \multirow{2}{*}{$\begin{array}{l}\mathrm{x}^{2}+\text { ax }+484 \text { üç terimli } \\
\text { cebirsel ifadenin bir tam kare } \\
\text { ifade belirtmesi için a doğal } \\
\text { sayısı kaç olmalıdır? }\end{array}$} & Kodlayıc1 1 & & 8 & Cebir & $\begin{array}{l}\text { Cebirsel ifadeler } \\
\text { ve özdeşlikler }\end{array}$ & Yok \\
\hline & Kodlayıc1 2 & & 8 & Cebir & $\begin{array}{l}\text { Cebirsel ifadeler } \\
\text { ve özdeşlikler }\end{array}$ & Yok \\
\hline \multirow{2}{*}{$\begin{array}{l}\text { Bir turist grubunda } 12 \text { erkek ve } \\
18 \text { kadın vardır. Gruptan bir } \\
\text { kişiye hediye verilecektir. } \\
\text { Erkeklerin mi yoksa kadınların } \\
\text { mı hediyeyi alma olasılığ1 daha } \\
\text { fazladır? Nedenini açılayınız. }\end{array}$} & Kodlayıc1 1 & & 8 & Olasilik & $\begin{array}{l}\text { Basit Olayların } \\
\text { Olma Olasilığ1 }\end{array}$ & $\begin{array}{c}\text { Evrenselcilik-Turist } \\
\text { grubu } \\
\text { Nezaket/ Hediye } \\
\text { vermek }\end{array}$ \\
\hline & Kodlayıcı 2 & & 8 & Olasilık & $\begin{array}{l}\text { Basit Olayların } \\
\text { Olma Olasılığ }\end{array}$ & $\begin{array}{c}\text { Evrenselcilik-Turist } \\
\text { grubu } \\
\text { Nezaket/ Hediye } \\
\text { vermek } \\
\text { Sevgi/Hediye vermek }\end{array}$ \\
\hline \multirow{2}{*}{$\begin{array}{l}\text { Evlerimizde kullandığımız } \\
\text { telefon, elektrik ve su faturalar } \\
\text { zamanında ödenmediğinde } \\
\text { hangi oranda gecikme bedeli } \\
\text { ödendiğini biliyor musunuz? }\end{array}$} & Kodlayıcı 1 & & 7 & $\begin{array}{l}\text { Sayllar ve } \\
\text { İşlemler }\end{array}$ & Yüzdeler & $\begin{array}{l}\text { Sorumluluk/Faturaları } \\
\text { nı zamanında ödemek }\end{array}$ \\
\hline & Kodlayıc 2 & & 7 & $\begin{array}{l}\text { Sayilar ve } \\
\text { İşlemler }\end{array}$ & Yüzdeler & $\begin{array}{l}\text { Sorumluluk/Faturaları } \\
\text { nı zamanında ödemek }\end{array}$ \\
\hline
\end{tabular}

Tablo 3' te görüldüğü üzere, matematik ders kitaplarında yer alan ifadelere (problemler, alıştırmalar, örnekler) sınıf düzeyi, öğrenme alanı, alt öğrenme alanı, ifadenin içerdiği sosyal değer ve bu sosyal değerin seçilme gerekçesine (göstergesine) yer verilmiştir. Ayrıca Tablo 3’ te iki farklı araştırmacı tarafindan yapılan kodlamalara yer verilmiştir. "Bir turist grubunda 12 erkek ve 18 kadin vardir. Gruptan bir kişsiye hediye verilecektir. Erkeklerin mi yoksa kadınlarm mı hediyeyi alma olasiluğ daha fąladır? Nedenini açılayımı:” Problem durumunda birinci kodlayıcı evrenselcilik ve nezaket değerlerine yer verildiğini ifade ederken, ikinci kodlayıcı bu iki değere ek olarak bu ifadede sevgi değerinin de olduğunu ifade etmiştir. Daha sonra araştırmacılar yaptıkları tartışmalar neticesinde hediye vermenin sevgi değerinin bir göstergesi olduğunu kabul ederek uzlaşıya varmışlardır. 


\section{BULGULAR}

Çalışmanın bu bölümünde ortaokul matematik ders kitaplarında yer alan problemlerin, etkinliklerin, örneklerin ve ödevlerin sosyal değerler açısından incelenmesi sonucu elde edilen bulgulara yer verilmiştir. Bulguların sunulmasında ilk olarak her sınıf düzeyi (5., 6., 7., 8.) için detaylı bir incelemeye yer verilmiştir. Daha sonra tüm sınıf düzeylerine ait sosyal değerler bir tablo yardımıyla karşılaştırılmıştır. Aşağıda yer alan Tablo 4' te beşinci sınıf ders kitabında yer alan sosyal değerlere ait bulgular yer almaktadır.

Tablo 4. Beşinci sınıf ders kitabında yer alan sosyal değerlere ait frekans tablosu

\begin{tabular}{|c|c|c|c|c|c|c|c|c|c|c|}
\hline $\begin{array}{l}\text { Öğrenme } \\
\text { Alanı }\end{array}$ & $\begin{array}{l}\text { Alt Öğrenme } \\
\text { Alanı }\end{array}$ & 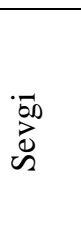 & $\begin{array}{l}\text { DD } \\
\text { तू }\end{array}$ & 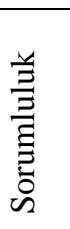 & 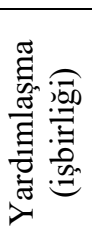 & 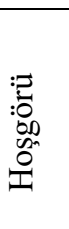 & 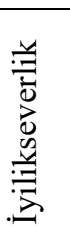 & 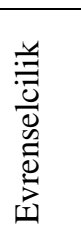 & 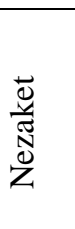 & $\frac{\Xi}{\frac{\pi}{0}}$ \\
\hline \multirow{7}{*}{ 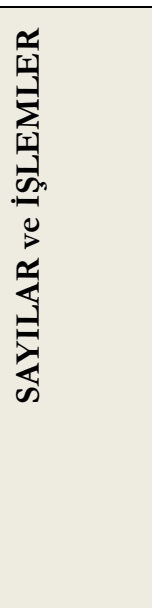 } & Doğal Sayılar & 2 & - & 4 & 2 & - & 1 & 4 & - & 13 \\
\hline & $\begin{array}{l}\text { Doğal Sayılarla } \\
\text { İşlemler }\end{array}$ & 3 & 1 & 15 & 8 & 2 & 5 & 6 & 4 & 44 \\
\hline & Kesirler & 6 & & 6 & 4 & 2 & 1 & 2 & 2 & 23 \\
\hline & $\begin{array}{l}\text { Kesirlerle } \\
\text { İşlemler }\end{array}$ & 1 & 1 & 2 & 2 & - & - & 3 & 1 & 10 \\
\hline & $\begin{array}{l}\text { Ondalık } \\
\text { Gösterim }\end{array}$ & 2 & 3 & 6 & 2 & - & - & 6 & 4 & 23 \\
\hline & Yüzdeler & 3 & 1 & 8 & 1 & 1 & - & 4 & - & 18 \\
\hline & Toplam & 17 & 6 & 41 & 19 & 5 & 7 & 25 & 11 & 131 \\
\hline \multirow{6}{*}{ 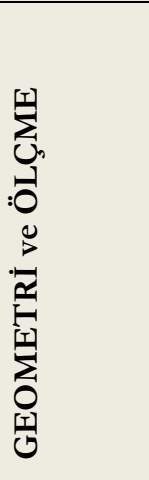 } & $\begin{array}{l}\text { Temel } \\
\text { Geometrik } \\
\text { Kavramlar ve } \\
\text { Çizimler }\end{array}$ & 2 & 2 & 2 & 1 & - & - & 3 & - & 10 \\
\hline & $\begin{array}{l}\text { Üçgenler ve } \\
\text { Dörtgenler }\end{array}$ & 1 & - & - & & - & - & 1 & - & 2 \\
\hline & $\begin{array}{l}\text { Uzunluk ve } \\
\text { Zaman Ölçme }\end{array}$ & 3 & - & 5 & 2 & - & - & 1 & - & 11 \\
\hline & Alan Ölçme & & - & - & 2 & - & - & 1 & - & 3 \\
\hline & $\begin{array}{l}\text { Geometrik } \\
\text { Cisimler }\end{array}$ & 1 & - & - & 1 & - & - & 2 & - & 4 \\
\hline & Toplam & 7 & 2 & 7 & 6 & - & - & 8 & - & 30 \\
\hline \multirow[t]{2}{*}{ 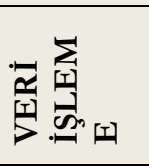 } & $\begin{array}{l}\text { Veri Toplama } \\
\text { ve } \\
\text { Değerlendirme }\end{array}$ & 3 & 1 & 3 & 1 & 1 & 1 & 4 & - & 14 \\
\hline & Toplam & 3 & 1 & 3 & 1 & 1 & 1 & 4 & - & 14 \\
\hline \multicolumn{2}{|c|}{ TOPLAM } & 27 & 9 & 51 & 26 & 6 & 8 & 37 & 11 & 175 \\
\hline
\end{tabular}

Tablo 4' te görüldüğü üzere; beşinci sınıf ders kitabında en fazla sorumluluk (51), yardımlaşma (26) ve evrenselcilik (37) değerlerinin yer aldığı görülmüştür. Buna rağmen beşinci sınıf ders kitabında sayg1 (9), hoşgörü (6), nezaket (11) ve iyilikseverlik (8) değerlerine ise daha az yer verildiği tespit edilmiştir. Öğrenme alanları açısından değerlendirildiğinde ise en fazla değere "Saynlar ve İslemler" öğrenme alanında (131) yer verildiği görülmüştür. "Geometri ve Ölçme” (30) ile "Veri İsleme” (14) öğrenme alanlarında ise değerlere daha az yer verildiği bulgusuna ulaşılmıştır. Beşinci sınıf ders kitabında daha çok herhangi bir sosyal değerin yer almadığ1 "213×604 işleminin sonucunu bulalım.” tarzındaki probleme yer verildiği görülmüştür. Buna rağmen

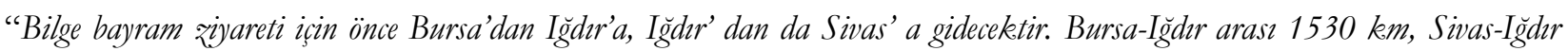
arası 729 km olduğuna göre Bilge'nin Bursa'dan Sivas'a yaklaşık kaç km gideceğini tahmin edelim...” tarzında sosyal değerler içeren ifadelere ise yeterince yer verilmediği söylenebilir. Ayrıca beşinci sınıf ders kitabında ünite başlarında genellikle sosyal değerler içere çeşitli kurum ve kuruluşların tanıtılması sosyal değerlerin kazandırılması açısından önemli bir bulgudur. 


\section{Kan Bağışı Hayat Kurtarır}

1868 'den bugüne birçok savas ve afette binlerce insana yardım eli uzatan Türk Kızılayı, gönüllü bağışçılardan alınan kanları intiyaç sahiplerine ulaștırmaktadır. Bağıșlanan bir ünite kan, 3 kișinin hayatını kurtarmaktadır. 17 bölgede kan bağıșı merkezi bulunan Kızılay'a, 2016 yılında Orta Karadeniz Bölgesi Kan Merkezi'nden 92 923, Bat Anadolu Bölgesi Kan Merkezi'nden 79 180, Doğu Anadolu Bölgesi Kan Merkezi'nden ise 51874 ünite kan bağıșı yapılmıștır.

Kan bağışının önemi hakkında ne düşünüyorsunuz? Her bölgeden az miktarda da olsa kan bağışı yapıldığında bu bağışlar nasıl bir fark oluşturur?

Bu üç bölgeden 2016 yılında tahmini kaç ünite bağış vapıımıș olabilir?

Şekil 1. Beşinci sınıf ders kitabından bir ünite başlangıç örneği (Cırıtıcı vd., 2017).

Şekil 1' de beşinci sınıf ders kitabının 'Doğal Saynlar ve İ̧slemler" konusunda yer alan ve öğrencilerin dikkatini çekmeyi, derse karşı güdülemeyi hedefleyen bir öğrenme etkinliği yer almaktadır. Bu etkinlikte; "KIZILAY" kurumu tanıtılmakta ve bu yapılırken de hayat kurtarmak, bağış yapmak, gönüllü bağışçllık, yardım eli uzatmak gibi sosyal değerler içeren ifadeler kullanılmıştır. Yani bu etkinlikle birlikte hem öğrencilere matematiksel bir kavram hem de iyilikseverlik, yardımlaşma, sorumluluk gibi sosyal değerler kazandırılmaya çalışılmaktadır. Zaten sosyal değerlerin ne kadar önemli olduğuna PISA sınavlarında matematik sorularının bir kısmına (\%25) toplumsal bağlamda yer verilmesi örnek olarak gösterilebilir. (Organisation for Economic Cooperation and Development [OECD], 2016). Aşağıda yer alan örnekte beşinci sınıf ders kitabında sorumluluk değerinden sonra en fazla yer alan değer olan everenselcilik değerine ait bir etkinliğe yer verilmiştir.

\section{Rubik Küp}

1974 yilında Macar Heykeltıraş ve Mimar Ernö Rubik tarafından bir ders aracı olarak üretilen ve daha sonra mekanik bir bulmaca hâlini alan Rubik Küp, sihirli küp ve zekâ küpü olarak da bilinmektedir.

O yıllarda karmaşık bir yapıya sahip olan bu küpün yapımı için bir üretici bulmak bir hayli zor olmuş.

Bu küpün üretimi için nasıl bir planlama yapılmış olabilir? Kâğıda küpün tüm yüzlerini görebilecek bir çizim yapmak sizce mümkün müdür? Nasıl?

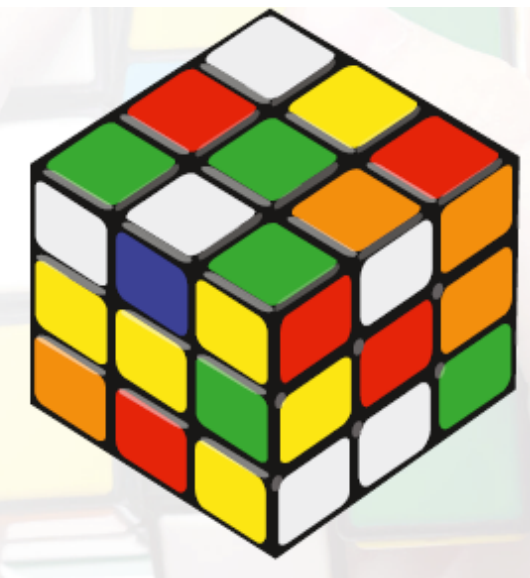

Şekil 2. Beşinci sınıf ders kitabından yer alan bir güdüleme etkinliği (Cırıııcı vd., 2017).

Şekil 2' de beşinci sınıf ders kitabının "Geometri ve Ölçme” konusunda yer alan ve öğrencilerin derse karşı dikkatini çekmeyi ve onları güdülemeyi hedefleyen bir etkinlik yer almaktadır. Bu etkinlikte; öğrencilere Macarlar tarafından keşfedilen ve günümüzde çocukların zeka gelişimlerine katkıda bulunmak için kullanılan rubik küp tanıtılmıştır. Bu etkinlikte farklı kültürlerin ele alınması öğrencilerde evrenselcilik sosyal değerinin gelişimine katkıda bulunabileceği söylenebilir. Aşağıda yer alan Şekil 3’te beşinci sınıf ders kitabında yer alan bir probleme yer verilmiştir.

Merve annesi için yaptırdığı bir buket çiçeğe 15 lira 75 kuruş, kardeşi için aldığı çikolataya 2 lira 49 kuruş ödemiștir. Merve'nin annesi ve kardeși için toplam kaç lira harcama yaptığını bulalım.

Şekil 3. Beşinci sınıf ders kitabında yer alan bir problem örneği (Cırıtıcı vd., 2017).

Şekil 3' te yer verilen ve "Saynlar ve İslemler" öğrenme alanına ait bu problem ifadesinde anne, kardeş gibi sevgi değerine ait göstergeler yer almaktadır. Ayrıca Merve' nin annesine çiçek yaptırması nezaket ve sevgi değerlerinin bir göstergesidir. Yani bu problem ifadesinde hem nezaket hem de sevgi sosyal değeri yer almaktadir. 
Aşağıda yer alan Tablo 5' te altıncı sınıf ders kitabında yer alan sosyal değerlere ait bulgular yer almaktadir.

Tablo 5. Altıncı sınıf ders kitabında yer alan sosyal değerlere ait frekans tablosu

\begin{tabular}{|c|c|c|c|c|c|c|c|c|c|c|}
\hline $\begin{array}{l}\text { Öğrenme } \\
\text { Alanı }\end{array}$ & $\begin{array}{l}\text { Alt Öğgrenme } \\
\text { Alanı }\end{array}$ & $\begin{array}{l}\text { क0 } \\
\overrightarrow{0} \\
\text { क }\end{array}$ & 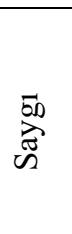 & 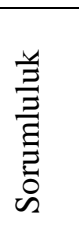 & 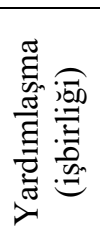 & $\begin{array}{l}:= \\
: 00 \\
: 00 \\
00 \\
0 \\
0 \\
1\end{array}$ & 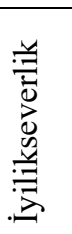 & 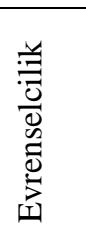 & 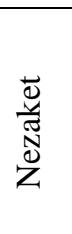 & 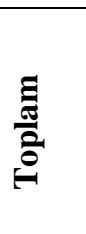 \\
\hline \multirow{7}{*}{ 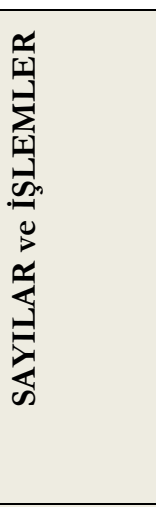 } & $\begin{array}{l}\text { Doğal Sayilarla } \\
\text { İşlemler }\end{array}$ & 2 & 1 & 2 & 1 & - & - & 1 & 1 & 8 \\
\hline & $\begin{array}{l}\text { Çarpanlar ve } \\
\text { Katlar }\end{array}$ & 1 & 2 & 1 & - & - & - & - & - & 4 \\
\hline & Oran & 1 & - & 2 & - & - & - & - & 1 & 4 \\
\hline & $\begin{array}{l}\text { Kesirlerle } \\
\text { İşlemler }\end{array}$ & 6 & 1 & 6 & 3 & - & 4 & 1 & - & 21 \\
\hline & $\begin{array}{l}\text { Ondalık } \\
\text { Gösterim }\end{array}$ & 2 & 1 & 4 & 2 & 1 & - & - & - & 10 \\
\hline & Tam Sayılar & 7 & - & 5 & 2 & - & 3 & 2 & - & 19 \\
\hline & Toplam & 19 & 5 & 20 & 8 & 1 & 7 & 4 & 2 & 66 \\
\hline \multirow{2}{*}{ 突. } & $\begin{array}{l}\text { Cebirsel } \\
\text { Iffadeler }\end{array}$ & 2 & - & - & - & - & - & - & - & 2 \\
\hline & Toplam & 2 & - & - & - & - & - & - & - & 2 \\
\hline \multirow{6}{*}{ 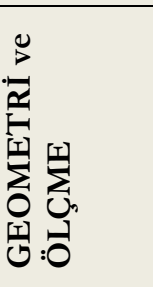 } & Açlar & - & - & - & - & - & - & - & - & - \\
\hline & Alan Ölçme & 5 & - & 4 & 1 & - & 1 & 4 & - & 15 \\
\hline & $\begin{array}{l}\text { Geometrik } \\
\text { Cisimler }\end{array}$ & 1 & - & 2 & - & - & - & 1 & 1 & 5 \\
\hline & Sıv1 Ölçme & 1 & - & & 1 & - & - & & - & 2 \\
\hline & Çember & 1 & - & & 1 & - & - & 1 & - & 3 \\
\hline & Toplam & 8 & - & 6 & 3 & - & 1 & 6 & 1 & 25 \\
\hline \multirow{4}{*}{ 胥夏夏 } & $\begin{array}{l}\text { Veri Toplama } \\
\text { ve } \\
\text { Değerlendirme }\end{array}$ & 2 & - & 2 & - & - & - & 4 & - & 8 \\
\hline & Veri Analizi & 4 & - & 3 & - & - & - & 1 & - & 8 \\
\hline & Toplam & 6 & - & 5 & - & - & - & 5 & - & 16 \\
\hline & PLAM & 35 & 5 & 31 & 11 & 1 & 8 & 15 & 3 & 109 \\
\hline
\end{tabular}

Tablo 5' te görüldüğü üzere; altıncı sinıf ders kitabinda en fazla sevgi (35) ve sorumluluk (31) değerlerine yer verildiği söylenebilir. Buna rağmen altıncı sınıf ders kitabında sayg1 (5), yardımlaşma (11), hoşgörü (1), iyilikseverlik (8) ve nezaket (3) değerlerine ise daha az yer verildiği görülmüştür. Öğrenme alanlar1 açısından değerlendirildiğinde ise değerlere en fazla Sayılar ve İşlemler öğrenme alanında (66) yer verildiği bulgusuna ulaşılmıştır. Cebir (2), Geometri ve Ölçme (25) ile Veri işleme (16) öğrenme alanlarında ise sosyal değerlere daha az yer verildiği tespit edilmiştir. Ayrıca altıncı sınıf ders kitabında "Bir orman yangınnda 5 bektarlı. alan yok olmustur. Bu alam tekerar ağaçlandirmak isteyen çevre gönüllüleri, her m²ye bir fidan dikmislerdir. Buna göre bu iş için kaç fidan kullanıldĭğm hesaplayalım.” şeklinde sosyal değerleri içeren problemlere yeterince yer verilmediği görülmektedir. Altıncı sınıf ders kitabındaki problemlerde daha çok "Yarısını 4 fazlasının 2 katı 20 olan sayıy hesaplayınæ:" ve "Tümlerinin ölçüsü kendisinin 3 katı olan açı kaç derecedir?" tarzındaki ifadelere yer verilmektedir. Yani altıncı sınıf ders kitabında yer alan problemlerin, örneklerin ve alıştırmaların genel olarak sosyal değerleri içermediği söylenebilir. Aşağıda yer alan Şekil 4 ve Şekil 5' te altıncı sınıf ders kitabında yer alan problemlere yer verilmiştir.

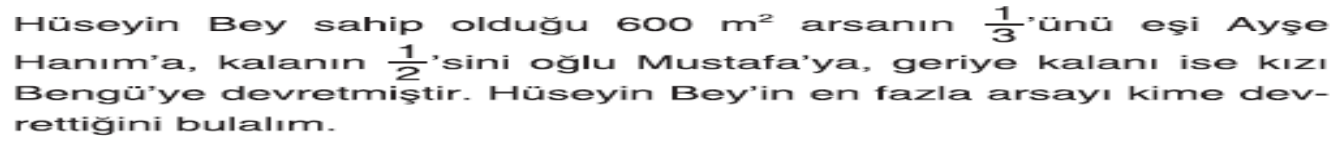

Şekil 4. Altıncı sınıf ders kitabından yer alan bir problem örneği (Cırıtıcı vd., 2017).

Şekil 4' te yer alan "Sayılar ve İslemler" öğrenme alanına ait bu problem ifadesinde yer alan "Bey" ve "Hanım" ifadelerinin nezaket sosyal değerine ait birer göstergedir. Ayrıca bu problemde yer alan eş, oğul ve kızı gibi ifadeler ise sevgi değerine ait gösterge olarak değerlendirilmiştir. Yani bu problem ifadesinde hem sevgi hem de nezaket sosyal değerleri yer almaktadır. 
Metin, bir su bardağını defterinin üzerine ters çevirip bir çember çiziyor. Bu çemberin çapını ve cevresini hesaplamak istiyor.

Metin'e yardım etmek ister misiniz?

Şekil 5. Altıncı sınıf ders kitabından yer alan bir problem örneği (Cırıtıcı vd., 2017).

Şekil 5' te “Geometri ve Ölçme” öğrenme alanına ait problem ifadesinde öğrencilere 'Metin' e yardım etmek ister misiniæ??" sorusu sorulmuştur. Bu soru ifadesi de zaten çok açı bir şekilde yardımlaşma sosyal değerinin bir göstergesidir. almaktadır.

Aşağıda yer alan Tablo 6' da yedinci sınıf ders kitabında yer alan sosyal değerlere ait bulgular yer

Tablo 6. Yedinci sinıf ders kitabında yer alan sosyal değerlere ait frekans tablosu

\begin{tabular}{|c|c|c|c|c|c|c|c|c|c|c|}
\hline $\begin{array}{l}\text { Öğrenme } \\
\text { Alanı }\end{array}$ & $\begin{array}{l}\text { Alt Öğrenme } \\
\text { Alanı }\end{array}$ & $\begin{array}{l}\text { DD } \\
\overrightarrow{0} \\
\text { is }\end{array}$ & $\begin{array}{l}\text { DD } \\
\overrightarrow{\tilde{H}}\end{array}$ & 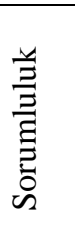 & 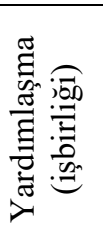 & $\begin{array}{l}:=0 \\
: 00 \\
000 \\
0 \\
0 \\
1 \\
1\end{array}$ & 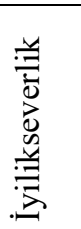 & 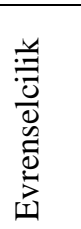 & 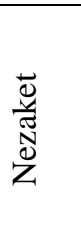 & $\frac{\Xi}{\frac{\pi}{2}}$ \\
\hline \multirow{6}{*}{ 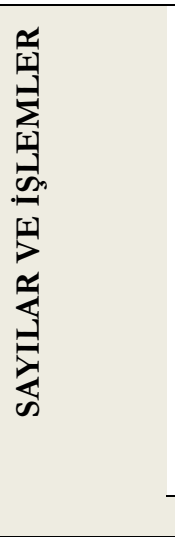 } & $\begin{array}{l}\text { Tam Sayılarla } \\
\text { İşlemler }\end{array}$ & 1 & - & 5 & 1 & - & - & 1 & & 8 \\
\hline & $\begin{array}{l}\text { Rasyonel } \\
\text { Savilar }\end{array}$ & 1 & - & - & 1 & - & - & - & 1 & 3 \\
\hline & $\begin{array}{l}\text { Rasyonel } \\
\text { Sayilarda } \\
\text { İşlemler }\end{array}$ & 5 & - & 10 & 1 & - & 4 & 2 & 2 & 24 \\
\hline & $\begin{array}{l}\text { Oran ve } \\
\text { Orant1 }\end{array}$ & 7 & 4 & 13 & 5 & - & 3 & 7 & 2 & 41 \\
\hline & Yüzdeler & 6 & 4 & 15 & 3 & - & 4 & 2 & 5 & 39 \\
\hline & Toplam & 20 & 8 & 43 & 11 & - & 11 & 12 & 10 & 115 \\
\hline \multirow{3}{*}{ 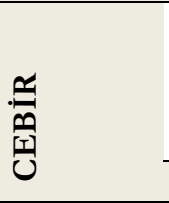 } & $\begin{array}{l}\text { Eşitlik ve } \\
\text { Denklem }\end{array}$ & 3 & - & 10 & 3 & - & 3 & 4 & 1 & 24 \\
\hline & $\begin{array}{l}\text { Doğrusal } \\
\text { Denklemler }\end{array}$ & 2 & - & 7 & 2 & 1 & 1 & 1 & 2 & 16 \\
\hline & Toplam & 5 & - & 17 & 5 & 1 & 4 & 5 & 3 & 40 \\
\hline \multirow{6}{*}{ 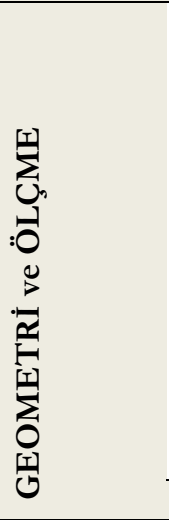 } & $\begin{array}{l}\text { Doğrular ve } \\
\text { Açılar }\end{array}$ & - & - & - & - & - & - & - & - & - \\
\hline & $\begin{array}{l}\text { Çember ve } \\
\text { Daire }\end{array}$ & 3 & - & 1 & - & - & - & 1 & - & 5 \\
\hline & Çokgenler & 2 & - & 4 & 2 & - & - & 1 & - & 9 \\
\hline & $\begin{array}{l}\text { Dönüşüm } \\
\text { Geometrisi }\end{array}$ & 1 & - & - & - & - & - & - & - & 1 \\
\hline & $\begin{array}{l}\text { Cisimlerin } \\
\text { Farklı } \\
\text { Yönlerden } \\
\text { Görünümleri }\end{array}$ & 1 & 1 & 2 & 1 & - & - & - & - & 5 \\
\hline & Toplam & 7 & 1 & 7 & 3 & - & - & 2 & & 20 \\
\hline \multirow{2}{*}{$>$ 되 묘 } & Veri Analizi & 9 & 1 & 16 & - & 1 & - & 4 & 1 & 32 \\
\hline & Toplam & 9 & 1 & 16 & - & 1 & - & 4 & 1 & 32 \\
\hline TO & PLAM & 41 & 10 & 83 & 19 & 2 & 15 & 23 & 14 & 207 \\
\hline
\end{tabular}

Tablo 6' da; yedinci sınıf ders kitabında en fazla sorumluluk (83) değerinin yer aldığı görülmektedir. Buna rağmen yedinci sınıf ders kitabında sayg1 (10), hoşgörü (2), nezaket (14) ve iyilikseverlik (15) değerlerine daha az yer verildiği görülmüştür. Öğrenme alanları açısından değerlendirildiğinde ise en fazla değere Sayılar ve İslemler öğrenme alanında (115) yer verildiği bulgusuna ulaşılmıştır. Geometri ve Ölçme (20) ve Veri İsleme (32) öğrenme alanlarında ise sosyal değerlere daha az yer verildiği görülmüştür. Ayrıca yedinci sınıf ders kitabında "Mebmet Bey, bir bankadan 1 yulliğna 20000 TL keredi çekiyor. Mehmet Bey, 1 ynlsonunda bankaya toplam 22400 TL ödüyor. Cekilen kredinin bir yullık faiz yüzdesini bulalım.” şeklinde sosyal değerleri içeren problemlere yeterince yer verilmediği sonucuna ulaşılmıştır. Yedinci sınıf ders kitabındaki problemlerde daha çok "Bir eş kenar üggenin bir kenar uzunluğunu $4 \mathrm{~cm}$ arturdiğmızda çevresinin uzunluğu $27 \mathrm{~cm}$ oluyor. Bu üggenin bir kenarmm uzunluğu kaç santimetredir?" tarzındaki ifadelere yer verildiği belirlenmiştir. Yani yedinci sınıf ders kitabında yer alan problemlerin, örneklerin ve alıştırmaların genel olarak sosyal değerleri içermediği söylenebilir. Aşağıda yer alan Şekil 6 ve Şekil 7’ de yedinci sınıf ders kitabında yer alan problemlere yer verilmiştir. 


\begin{abstract}
OORNEK $A$
Bir oteldeki görevli zeminin 3 kat altındaki otoparktan aldığı bavulları asansörle 9. kata tașıdıktan sonra tekrar asansörle otoparka inecektir. Bavulların ağırlığı asansörün taşıma kapasitesini aşmayacak şekilde bavulları birkaç sefer yaparak asansörle taşıyan görevli toplam 48 kat yer değiştirdiğine göre kaç sefer yapmıştır?
\end{abstract}

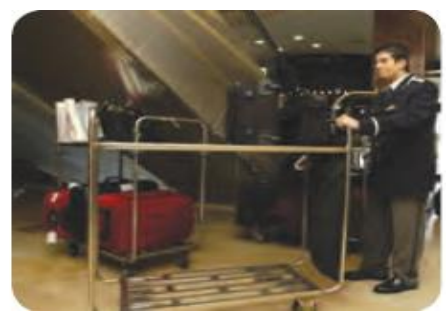

Şekil 6. Yedinci sınıf ders kitabından yer alan bir problem örneği (Bilen, 2017).

Şekil 6' da yer alan "Saynlar ve İ̧slemler" öğrenme alanına ait bu problem durumunda yer alan "bavullarn ağırly̆gmın asansörün kapasitesini aşmayacak şekilde” ifadesiyle asansör görevlisinin sorumluluk değerine uygun bir davranış örneği sergilediği görülmektedir. Yani bu tarz problem durumları öğrencilerin sorumluluk bilinci kazanmalarına yardımcı olabilir.
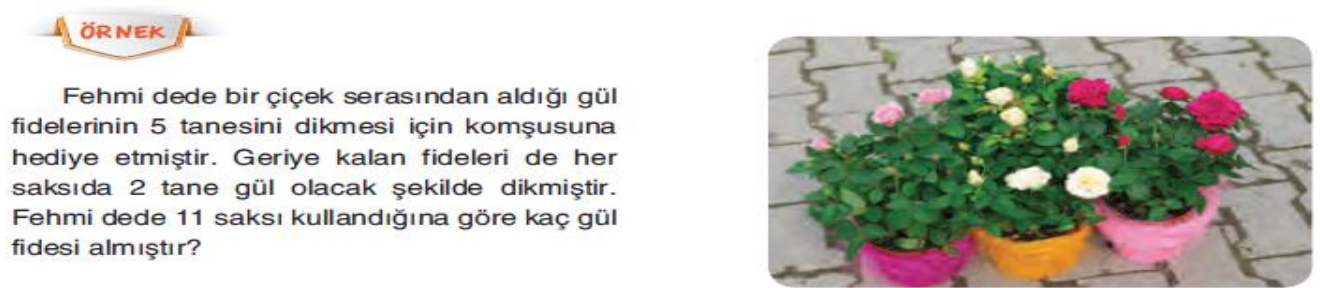

Şekil 7. Yedinci sınıf ders kitabından yer alan bir problem örneği (Bilen, 2017).

Şekil 7' de yer verilen ve "Cebir" öğrenme alanına ait bu örnekte nezaket, sayg1 ve sevgi sosyal değerlerine yer verilmiştir. Örnek ifadede yer alan "bediye etmek" nezaket ve sevgi, "Fehmi dede" sayg1 sosyal değerlerinin birer göstergesidir. Ayrıca problem ifadesinde çiçek resimlerine yer verilmesiyle ve çiçek dikme durumundan bahsedilmesiyle öğrencilere doğa sevgisinin kazandırmaya çalışıldığı söylenebilir.

Aşağıda yer alan Tablo 7’ de sekizinci sınıf ders kitabında yer alan sosyal değerlere ait bulgular yer almaktadir.

Tablo 7. Sekizinci sınıf ders kitabında yer alan sosyal değerlere ait frekans tablosu

\begin{tabular}{|c|c|c|c|c|c|c|c|c|c|c|}
\hline $\begin{array}{l}\text { Öğrenme } \\
\text { Alanı }\end{array}$ & $\begin{array}{l}\text { Alt Öğrenme } \\
\text { Alanı }\end{array}$ & $\begin{array}{l}\text { DD } \\
\text { d } \\
\tilde{\omega}\end{array}$ & $\begin{array}{l}\text { DD } \\
\widehat{E}_{\mathscr{N}}\end{array}$ & 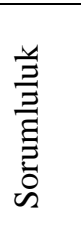 & 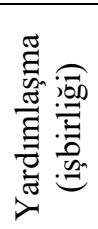 & 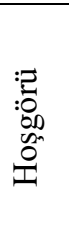 & 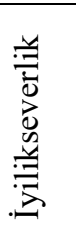 & 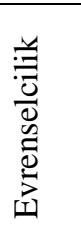 & $\begin{array}{l}\overline{0} \\
\text { 芯 } \\
\text { d } \\
Z\end{array}$ & $\frac{\Xi}{\stackrel{\Xi}{0}}$ \\
\hline \multirow{4}{*}{ 孚䍃 } & $\begin{array}{l}\text { Çarpanlar ve } \\
\text { Katlar }\end{array}$ & - & 3 & 2 & - & - & 1 & - & 4 & 10 \\
\hline & Üslü İfadeler & - & - & - & - & - & - & 3 & - & 3 \\
\hline & $\begin{array}{l}\text { Kareköklü } \\
\text { İfadeler }\end{array}$ & 2 & 1 & - & 1 & - & - & 3 & 1 & 8 \\
\hline & Toplam & 2 & 4 & 2 & 1 & - & 1 & 6 & 5 & 21 \\
\hline \multirow{4}{*}{ 菊 } & $\begin{array}{l}\text { Cebirsel } \\
\text { ifadeler ve } \\
\text { Özdeşlikler }\end{array}$ & 1 & 1 & - & - & - & - & 1 & 1 & 4 \\
\hline & $\begin{array}{l}\text { Doğrusal } \\
\text { Denklemler }\end{array}$ & 7 & 2 & 9 & 1 & 1 & - & 4 & 4 & 28 \\
\hline & Eşitsizlikler & 2 & 4 & 8 & - & - & - & - & 2 & 16 \\
\hline & Toplam & 10 & 7 & 17 & 1 & 1 & - & 5 & 7 & 48 \\
\hline \multirow{5}{*}{ 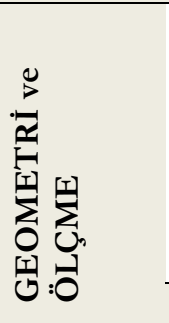 } & Üंçgenler & 2 & 2 & 3 & - & - & 1 & 2 & - & 10 \\
\hline & $\begin{array}{l}\text { Dönüşüm } \\
\text { Geometrisi }\end{array}$ & 3 & 1 & 1 & 1 & - & - & 1 & 1 & 8 \\
\hline & $\begin{array}{l}\text { Eşlik ve } \\
\text { Benzerlik }\end{array}$ & - & - & 1 & - & - & - & 2 & - & 3 \\
\hline & $\begin{array}{l}\text { Geometrik } \\
\text { Cisimler }\end{array}$ & 3 & 3 & 4 & 2 & - & - & 5 & 1 & 18 \\
\hline & Toplam & 8 & 6 & 9 & 3 & - & 1 & 10 & 2 & 39 \\
\hline \multirow{2}{*}{$>$ 띠 } & Veri Analizi & 5 & 1 & 12 & 1 & 1 & - & 1 & - & 21 \\
\hline & Toplam & 5 & 1 & 12 & 1 & 1 & - & 1 & - & 21 \\
\hline \multirow{2}{*}{ 出寻州 } & $\begin{array}{l}\text { Basit Olayların } \\
\text { Olma Olasılığ1 }\end{array}$ & 6 & - & 3 & 1 & 1 & 2 & - & 3 & 16 \\
\hline & Toplam & 6 & & 3 & 1 & 1 & 2 & - & 3 & 16 \\
\hline \multicolumn{2}{|c|}{ TOPLAM } & 31 & 18 & 43 & 7 & 3 & 4 & 22 & 17 & 145 \\
\hline
\end{tabular}


Tablo 7' de; sekizinci sınıf ders kitabında en fazla sorumluluk (43) değerinin yer aldığı görülmektedir. Buna rağmen sekizinci sınıf ders kitabında yardımlaşma (7), hoşgörü (3) ve iyilikseverlik (4) sosyal değerlerine daha az yer verildiği bulgusuna ulaşılmıştır. Öğrenme alanları açısından değerlendirildiğinde ise en fazla sosyal değere Cebir (48) ile Geometri ve Ölçme (39) öğrenme alanlarında yer verildiği belirlenmiştir. Saynlar ve İslemler (21), Olasılke (16) ile Veri işleme (21) öğrenme alanlarında ise sosyal değerlere daha az yer verildiği görülmüştür. Ayrıca sekizinci sınıf ders kitabında "Esra arkadassına hediye etmek için yandaki listede isimleri verilen kitaplardan birini seçecektir. Esra'nın kaç farkh seçim yapabileceğini bulunu: (Sinekli Bakkal, Çalıkuşu, Yaban...)” şeklinde sosyal değerleri içeren problemlere yeterince yer verilmediği sonucuna ulaşılmıştır. Sekizinci sınıf ders kitabındaki problemlerde daha çok "Toplamlar 525, farklar 115 olan sayılar bulunuz:" tarzındaki ifadelere yer verildiği görülmektedir. Yani sekizinci sınıf ders kitabında yer alan problemlerin, örneklerin ve alıştırmaların genel olarak sosyal değerleri içermediği söylenebilir. Bunlara ek olarak; aşağıda yer alan Şekil 8'den görüldüğü gibi sekizinci sınıf ders kitabında nezaket göstergesi "bey" ve "banım" gibi ifadelere dikkat edildiği bulgusuna ulaşılmıştır.

Çiftcci Mehmet Bey yetiştirdiği 60 kg cevizi torbalara eşit miktarlarda koyarak satmak istiyor. Torbaların kaçar kilogram olabileceğini bulalım.

60 doğal sayısının çarpanlarını belirleyerek torbaların kaçar kg olabileceğini buluruz.

Çarpan ağacını kullanalım:

Çarpan ağacı

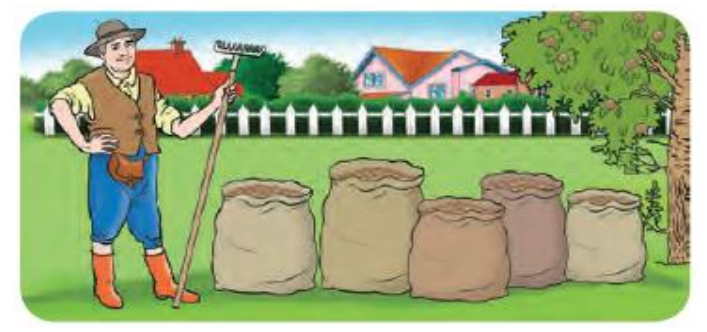

Şekil 8. Sekizinci sınıf ders kitabından yer alan bir problem örneği (Üstündağ Pektaş, 2017).

Aşağıda yer alan Tablo 8' de ortaokul matematik ders kitaplarının birlikte değerlendirilmesine ait bulgular yer almaktadir.

Tablo 8. Ortaokul ders kitaplarında yer alan sosyal değerlere ait frekans tablosu

\begin{tabular}{|c|c|c|c|c|c|c|c|c|c|c|}
\hline $\begin{array}{l}\text { Sinıf } \\
\text { Düzeyi }\end{array}$ & $\begin{array}{l}\text { Öğrenme } \\
\text { Alanı }\end{array}$ & 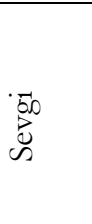 & 点 & 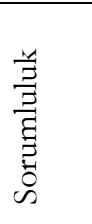 & 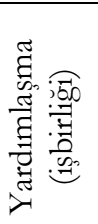 & 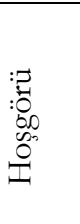 & 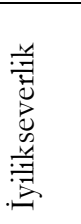 & 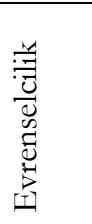 & 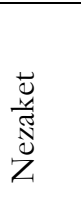 & 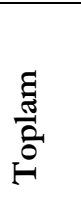 \\
\hline \multirow[t]{4}{*}{ 5.SINIF } & $\begin{array}{l}\text { Sayular ve } \\
\text { Islemler }\end{array}$ & 17 & 6 & 41 & 19 & 5 & 7 & 25 & 11 & 131 \\
\hline & $\begin{array}{l}\text { Geometrive } \\
\text { Ölcme }\end{array}$ & 7 & 2 & 7 & 6 & - & - & 8 & - & 30 \\
\hline & Veri $\dot{I}_{s}$ sleme & 3 & 1 & 3 & 1 & 1 & 1 & 4 & - & 14 \\
\hline & Toplam & 27 & 9 & 51 & 26 & 6 & 8 & 37 & 11 & 175 \\
\hline \multirow[t]{5}{*}{ 6.SINIF } & $\begin{array}{l}\text { Sayular ve } \\
\text { Islemler }\end{array}$ & 19 & 5 & 20 & 8 & 1 & 7 & 4 & 2 & 66 \\
\hline & Cebir & 2 & - & - & - & - & - & - & - & 2 \\
\hline & $\begin{array}{l}\text { Geometrive } \\
\text { Ölcme }\end{array}$ & 8 & - & 6 & 3 & - & 1 & 6 & 1 & 25 \\
\hline & Veri $\dot{I}_{s}$ leme & 6 & - & 5 & - & - & - & 5 & - & 16 \\
\hline & Toplam & 35 & 5 & 31 & 11 & 1 & 8 & 15 & 3 & 109 \\
\hline \multirow[t]{5}{*}{ 7.SINIF } & $\begin{array}{l}\text { Saynlar ve } \\
\text { İslemler }\end{array}$ & 20 & 8 & 43 & 11 & - & 11 & 12 & 10 & 115 \\
\hline & Cebir & 5 & - & 17 & 5 & 1 & 4 & 5 & 3 & 40 \\
\hline & $\begin{array}{l}\text { Geometrive } \\
\text { Ölcme }\end{array}$ & 7 & 1 & 7 & 3 & - & - & 2 & & 20 \\
\hline & Veri $\dot{I}_{s}$ leme & 9 & 1 & 16 & - & 1 & - & 4 & 1 & 32 \\
\hline & Toplam & 41 & 10 & 83 & 19 & 2 & 15 & 23 & 14 & 207 \\
\hline \multirow[t]{7}{*}{ 8.SINIF } & $\begin{array}{l}\text { Saynlar ve } \\
\text { Islemler }\end{array}$ & 2 & 4 & 2 & 1 & - & 1 & 6 & 5 & 21 \\
\hline & Cebir & 10 & 7 & 17 & 1 & 1 & - & 5 & 7 & 48 \\
\hline & $\begin{array}{l}\text { Geometrive } \\
\text { Ölçme }\end{array}$ & 8 & 6 & 9 & 3 & - & 1 & 10 & 2 & 39 \\
\hline & Veri $\dot{I}_{s}$ sleme & 5 & 1 & 12 & 1 & 1 & - & 1 & - & 21 \\
\hline & Olasilik & 6 & & 3 & 1 & 1 & 2 & - & 3 & 16 \\
\hline & Toplam & 31 & 18 & 43 & 7 & 3 & 4 & 22 & 17 & 145 \\
\hline & PPLAM & 134 & 42 & 208 & 63 & 12 & 35 & 97 & 45 & \\
\hline
\end{tabular}


Tablo 8’ de görüldüğü üzere; en fazla sosyal değere yedinci sınıf ders kitabında (207) yer verilirken, en az sosyal değere ise altıncı sınıf ders kitabında yer verilmiştir. Ders kitapları genel olarak değerlendirildiğinde ise; ders kitaplarında en fazla sorumluluk (208) değerine yer verilirken, en az hoşgörü (12) değerine yer verilmiştir. Ayrıca sekizinci sınıf ders kitabı hariç diğer kitaplarda; en fazla sosyal değere Sayılar ve İslemler öğrenme alanında yer verilmektedir.

\section{TARTIŞMA ve SONUÇLAR}

2017 y1lında yenilenen ögretim programlarında değerler eğitimine ayrı bir bölümde yer verilmesi değerler eğitiminin önemini ortaya koymaktadır (Baş, 2017). Bu çalışmada daha önce değinildiği gibi ders kitapları ögretim programlarının hedeflerinin gerçekleştirilmesinde en önemli unsurlardan biridir. Değerlerin ders kitapları üzerinden incelendiği birçok çalışma (Sezer, 2005; Güzel Candan ve Ergen, 2014; K1lıç ve Aktan, 2015; İnan Kılıç, 2009; Merey ve Karatekin, 2013; Özkan, 2017) değer kazandırmada ders kitaplarının önemini ortaya koymaktadır. Bu nedenle bu çalışmada matematik dersi kitapları sosyal değerler açısından incelenmiştir.

Çalışma sonucunda beşinci sınıf ders kitabında en fazla yer alan sosyal değerler sırasıyla; sorumluluk, evrenselcilik, sevgi ve yardımlaşmadır. Buna rağmen beşinci sınıf ders kitabında en az yer alan sosyal değerler sırasıyla; hoşgörü, iyilikseverlik, saygı ve nezakettir. Öğrenme alanları açısından değerlendirildiğinde ise, beşinci sınıf ders kitabında en fazla sosyal değere "Sayılar ve İslemler" öğrenme alanında yer verilirken en az değere ise "Veri İ̧leme” öğrenme alanında yer verildiği görülmüştür.

Altıncı sınıf ders kitabında en fazla yer alan sosyal değerler sırasıyla; sevgi ve sorumluluktur. Buna rağmen altıncı sınıf ders kitabında en az yer alan sosyal değerler sırasıyla; hoşgörü, nezaket, saygı, iyilikseverlik, yardımlaşma ve evrenselciliktir. Öğrenme alanları açısından değerlendirildiğinde ise, altıncı sınıf ders kitabında

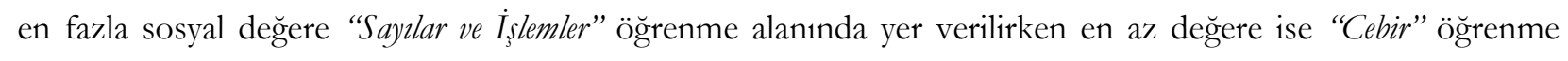
alanında yer verildiği görülmüştür.

Yedinci sınıf ders kitabında en fazla yer alan sosyal değerler sırasıyla; sorumluluk ve sevgi değerleridir. Buna rağmen yedinci sınıf ders kitabında en az yer alan sosyal değerler sırasıyla; hoşgörü, saygı, nezaket, iyilikseverlik, yardımlaşma ve evrenselciliktir. Öğrenme alanları açısından değerlendirildiğinde ise, yedinci sınıf ders kitabında en fazla sosyal değere "Saynlar ve Isslemler" öğrenme alanında yer verilirken en az değere ise “Geometri ve Ölçme” öğrenme alanında yer verildiği görülmüştür.

Sekizinci sınıf ders kitabında en fazla yer alan sosyal değerler sırasıyla; sorumluluk ve sevgi değerleridir. Buna rağmen sekizinci sınıf ders kitabında en az yer alan sosyal değerler sırasıyla; hoşgörü, iyilikseverlik, yardımlaşma, nezaket, saygı ve evrenselciliktir. Öğrenme alanları açısından değerlendirildiğinde ise, sekizinci sınıf ders kitabında en fazla sosyal değere "Cebir" öğrenme alanında yer verilirken en az değere ise "Olasılık." ögrenme alanında yer verildiği görülmüştür.

Çalışma sonucunda ders kitapları birlikte değerlendirildiğinde, en fazla sosyal değere yedinci sınıf ders kitabında yer verilirken en az sosyal değere ise altıncı sınıf ders kitabında yer verilmiştir. Ayrıca ders kitapları birlikte değerlendirildiğinde en fazla yer alan sosyal değerler sırasıyla; sorumluluk, sevgi, evrenselcilik ve yardımlaşmadır. Buna rağmen matematik ders kitaplarında en az yer alan sosyal değerler sırasıyla; hoşgörü, iyilikseverlik, sayg1 ve nezakettir. İlgili literatürde (Güzel Candan ve Ergen, 2014; Kılıç ve Aktan, 2015; Kuş, Merey\& Karatekin, 2013; Özkan, 2017) ders kitaplanında yer alan sosyal değerlerin incelenmesine yönelik çalışmalarda bu çalışmayla uyuşan ve uyuşmayan sonuçlara ve ulaşılmışır. Kılıç ve Aktan (2015) tarafından ilköğretim okullarında öğrenim gören çocuklar için önerilen yüz temel eserde yer alan değerleri inceleyen bir çalışma gerçekleştirilmiştir. Bu çalışma sonucunda bu temel eserlerde en fazla ve en az yer verilen değerler sırasıyla ifade edilmiştir. Ayrıca yerli ve yabancı eserlerde önem verilen değerlerin farklılaştığı görülmüştür. Fakat hem yerli hem de yabancı eserlerde en fazla yer alan iki değer sırasıyla sevgi ve yardımseverlik olarak ortaya konmuştur. Kılıç ve Aktan (2015)' in temel eserlerde ulaştı̆̆ı değerlerle bu araştırmada ulaşılan değerler uyuşmakla birlikte değerlerin önem sırası farklılık göstermektedir. Çünkü bu çalışmada, matematik ders 
kitaplarında en fazla sorumluluk değeri yer alırken, daha sonra en fazla sevgi değerine yer verildiği sonucuna ulaşılmıştır.

Güzel Candan ve Ergen (2014) yaptıkları çalışma sonucunda İlköğretim üçüncü sınıf Hayat Bilgisi ders kitaplarında en çok yer verilen değerlerin sevgi ve sorumluluk olduğunu ifade ederken, en az ele alınan değerlerin ise misafirperverlik ve barış değerleri olduğu sonucuna ulaşmışlardır. Güzel Candan ve Ergen (2014)' ün ulaştığı sonuç bu araştırmayla paralellik göstermektedir. Çünkü bu araştırmada da en fazla yer alan sosyal değerler sorumluluk ve sevgi değerleridir. Kuş, Merey ve Karatekin (2013) ise ilköğretim dördüncü ve beşinci sınıf sosyal bilgiler ders kitaplarında en sık vurgulanan değerlerin duyarlılık, vatanseverlik, sorumluluk, sevgi ve dayanışma olduğunu ifade ederken temizlik, dürüstlük ve hoşgörü değerlerinin ise en az yer verilen değerler olduğunu ifade etmisslerdir. Kuş, Merey ve Karatekin (2013)' in ulaştığı en fazla yer verilen değerlerde sorumluluğa ve en az yer verilen değerler arasında ise hoşgörüye yer verilmesi bu çalışmanın bulgularıyla örtüşmektedir. Özkan (2017) de yaptığı çalışma sonucunda hayat bilgisi ders kitaplarında en fazla sevgi değerinin yer aldığını belirtmiştir. İlgili literatürün tartışılması sonucunda, sevgi ve sorumluluk sosyal değerlerinin ders kitaplarında en fazla yer verilen sosyal değerler arasında yer aldığı görülmüştür. Buna rağmen hoşgörü değeri ise ders kitaplarında en az yer verilen sosyal değerler arasında yer verildiği tespit edilmiştir.

Bir dersin amacı öğrencilere sadece bilişsel beceriler kazandırmak değil aynı zamanda onların iyi bir vatandaş, iyi bir birey olmalarını sağlamaktır (MEB, 2017). Diğer bir ifadeyle, artık günümüzde matematik dersiyle öğrencilere sadece matematiksel bilgi ve becerileri kazandırmış olmamız yeterli değildir. Bir toplumun hedeflerine uygun yetişen bireylerin de o topluma, kültüre ve ülkeye ait değerlere sahip olmaları gerekmektedir. $\mathrm{Bu}$ değerlerin kazandırılmasında en önemli etkenlerden birisi de öğretim programlarının uygulanmasını sağlayan ders kitaplarıdır (MEB, 2017). Bundan dolayı Matematik Öğretim Programı'nda öngörülen nitelikteki bireylerin yetişmesi için ders kitaplarında belirli standartlar sağlanmalıdır. Fakat bu çalışmada, farklı yayın evleri tarafindan hazırlanan farklı sınıf düzeylerindeki matematik ders kitaplarında sosyal değerler farklı şekillerde ele alınmıştır. Ders kitaplarında ve diğer kitaplarda yer alan değerlere yönelik çalışmalar incelendiğinde (Kılıç \& Aktan, 2015) hangi değerlere daha çok, hangi değerlere daha az yer verildiği yaşanan ülkeye, kitabı yazan yazarlara, yayın evlerine göre değiştiği söylenebilir. Bundan dolayı ortaokul matematik ders kitaplarında sosyal değerler açısından standart sağlanması gerektiği söylenebilir.

\section{5. ÖNERIILER}

Çalışmanın bu bölümünde araştırmanın sonuçları doğrultusunda yapılan öneriler maddeler halinde sıralanmıştır.

- Bu çalışmada ortaokul matematik ders kitaplarında yer alan sosyal değerler incelenmiştir. İlkokul matematik ders kitaplarının incelenmesine yönelik araştırmalar yapılabilir.

- Bu çalışma sonucunda farklı yayınevleri tarafinda hazırlanan matematik ders kitaplarında sosyal değerlere farklı şekillerde yer verildiği görülmüsstür. $\mathrm{Bu}$ bağlamda ders kitaplarının hazırlanmasında ülkenin yetiştirmeyi hedeflediği insan profili dikkate alınarak bir standart geliştirilebilir.

- Matematik ders kitaplarında hoşgörü, iyilikseverlik, sayg1 ve nezaket sosyal değerlerine daha fazla yer verilmesi gerekmektedir.

- Ortaokul matematik öğretmenlerinin derslerinde kullandıkları örneklerde, problemlerde veya alıştırmalarda sosyal değerlere yer verip vermediklerini inceleyen bir araştırma gerçekleştirilebilir.

- Matematik derslerinin sosyal değerlerinin gelişimine etkisini incelemek için yarı deneysel çalışmalar yapılabilir. 


\section{KAYNAKÇA}

Akbaba-Altun, S. (2003). Eğitim yönetimi ve değerler. Değerler Ĕ̈̆timi Dergisi, 1(1), 7-18.

Akbaş, O. (2008). Sosyal bilgilerde değerler öğretimi. Özel ögrretim yöntemleriyle sosyal bilgiler ögrretimi (Ed. Bayram Tay ve Adem Öcal), Ankara: Pegem Akademi.

Balat Uyanık, G., \& Dağal Balaban, A. (2006). Okul öncesi dönemde değerler eğitimi etkinlikleri. 1. Bask1. Ankara: Kök Yayınları.

Baş, Murat. (2017). 2009 ve 2015 İlkokul matematik dersi öğretim programları ile 2017 ilkokul matematik dersi öğretim programı karşılaştırması. Yü̃üncü Yll Üniversitesi Eğitim Fakültesi Dergisi, 14(1), 1219-1258.

Bishop, A. J. (1999). Mathematics teaching and values education-An intersection in need of research. ZDM, 31(1), 1-4.

Can, G. (2002). Kişilike gelişimi. Gelişim ve ögrenme psikolojisi. Pegema Yayınc1lı, Ankara

Coombs-Richardson, R. \& Tolson H. (2005). A comparison of values rankings for selected American and Australian teachers. Journal of Research in International Education, 4, 263-277.

Creswell, J. W. (2011). Educational research: planning, conducting, and evaluating quantitative and qualitative research (4th Ed). Pearson Publications,Inc.

Dede, Y. (2006a). Lise matematik ders kitaplarında taşınan matematiksel değerler. Kuram ve Uygulamada Eğitim Bilimleri, 6 (1), 81-132.

Dede, Y. (2006b). Values in Turkish middle school mathematics textbooks. Quality and Quantity, 40(3), 331359.

Dede, Y. (2007). Matematik öğretiminde değerlerin yeri. Abant İzæet Baysal Üniversitesi Eğitim Fakültesi Dergisi, $7(1), 12-25$.

Denscombe, M. (2010). The good research guide: for small-scale social research projects. 4th Edition, Open University Press.

Dilmaç, B., \& Ekşi, H. (2007). Değerler eğitiminde temel tartısmalar ve temel yaklaşımlar. İlköğretmen Eğitimci Dergisi, 14, 21-29.

Erden, M. (1998). Öğretmenlik mesleğine giriş. İstanbul: Alkım Yayınları.

Gudmunsdottir, S. (1991). Values in pedagogical content knowledge. Journal of Teacher Education, 41(3), 44-52.

Gül, U. M. (2017). Türkçe ders kitabındaki metinlerin (5. sınıf) değerler eğitimi yaklaşımıyla incelenmesi. Erciyes Journal of Education [EJE], 1(1), 59-78.

Güven, Sami (1999), Toplumbilim, Ezgi Kitabevi, Bursa.

Güngör, E. (1993). Değerler psikolojisi. Amsterdam: Hollanda Türk Akademisyenler Birliği Vakfi Yayınları.

Güzel Candan, D., Ergen, G. (2014). 3. sınıf hayat bilgisi ders kitaplarının temel evrensel değerleri içermesi bakımından incelenmesi. Uşak Üniversitesi Sosyal Bilimler Dergisi, 7 (1), 134-161

Haydon, G. (2006). Values in education. London: Continuum International Pubblishing Group.

Izgar, G.(2013). Illkögretim okulu 8. sinf ögrencilerine uygulanan değerler eğitimi programmmn demokratik tutum ve davranışlarna etkisi. Doktora tezi, Necmettin Erbakan Üniversitesi Eğitim Bilimleri Enstitüsü, Konya.

İnan Kilıç, A. (2009). Yüz temel eserde dini ve ablaki değerler. Yüksek lisans tezi, Ondokuz Mayıs Üniversitesi Sosyal Bilimler Enstitüsü, Samsun.

Kılıç, A., \& Aktan, O. (2015). İlköğretim okulları için tavsiye edilen 100 temel eserde vurgulanan değerler. İlkögretim Online, 14(1), 243-275.

Kıncal, R. (2007). Vatandaşlik bilgisi. Ankara: Nobel Yayınları.

Kirschenbaum, H. (1995). Enhance values and morality. Boston: Allyn and Bacon.

Körükçü, Ö., Kapıkıran, N. A., \& Aral, N. (2016). Resimli çocuk kitaplarında Schwartz’ın modeline göre değerlerin incelenmesi. Mehmet Akif Ersoy Üniversitesi Eğitim Fakültesi Dergisi, 1(38), 133-151.

Kuş, Z., Merey, Z., \& Karatekin, K. (2013). İlköğretim 4. ve 5. sınıf sosyal bilgiler ders kitaplarında yer alan değerler. Değerler Ë̈̆timi Dergisi, 11(25), 183-214.

Kuşdil, M. E., \& Kağitçibaşi, Ç. (2000). Türk öğretmenlerin değer yönelimleri ve Schwartz değer kurami. Türk Psikoloji Dergisi. 15(45), 59-76.

Lickona, T. (2009). Educating for character: How our schools can teach respect and responsibility. Bantam.

Lyons, S. (2003). An exploration of generational values in life and at work. Unpublished doctoral dissertation, Carleton University, Canada.

MEB, (2007). Milli eğitim bakanlı̆̆1 ders kitapları ve eğitim araçları yönetmeliği. http://mevzuat.meb.gov.tr/html/27449 $0 . \mathrm{html}$ adresinden 28.02.2018 tarihinde alınmıştır.

MEB, (2017). Matematik dersi öğretim programı (ilkokul ve ortaokul 1,2,3,4,5, 6, 7 ve 8. sinıflar). http://mufredat.meb.gov.tr/ProgramDetay.aspx?PID=329 adresinden 14 Mart 2018 tarihinde indirilmiştir. 
MacIntyre, A. (2000). Philosophy for children: how philosophical enquiry can foster values education in schools. Education for values: Morals, ethics and citizenship in contemporary teaching, 50.

Mcmillian, H. J.\& Schumacher, S. (2010). Research in education. Boston, USA: Pearson Education

Naylor, D. T., \& Diem, R. A. (1987). Elementary and middle school social studies. Amer School Pub.

Neuman, W. L. (2014). Social research methods: qualitative and quantitative approaches (7th ed.). London: Pearson Education (yok)

Organisation for Economic Co-operation and Development. (2016). PISA 2015 Assessment and Analytical Framework: Science, Reading, Mathematic and Financial Literacy. OECD publishing.

Özkan, R. (2010). Türk eğitim sisteminde himayeci değerler: ilköğretim ders kitapları örneği. Uluslararası İnsan Bilimleri Dergisi, 7 (1), 1124-1140.

Özkan, Z. S. (2017). Hayat bilgisi ders kitaplarndaki metin ve görsellerin değerler açısından incelenmesi. Yayınlanmamış Yüksek Lisans Tezi, Ordu Üniversitesi Sosyal Bilimler Enstitüsü.

Raths, L. E., Harmin,M. ve Simon,S. B. (1978). Values and Teaching: working with values in the classroom. Ohio: Charles E. Merrill Books Inc.

Rokeach, M. (1973). The nature of human values. New York: Free Pres.

Sanchez, T. R. (1998). Using stories about heroes to teach values. ERIC Clearinghouse for Social Studies/Social Science Education.

Schwartz, (1992). Universals in the content and structure of values: Theoretical advances and emprical tests in 20 countries. Advances in Experimental Social Psychology, 25, 1-65.

Schwartz, S. H. (2012). An overview of the Schwartz theory of basic values. Online readings in Psychology and Culture, 2 (1).

Seah, W. T. \& Bishop, A. J. (2000). Values in mathematics textbooks: a Wiew throught The Australasian Regions. Paper Presented at the Annual Meeting of the American Educational Research Association, New Orleans, LA.

Sennett, R. (2003). Respect in a world of inequality. New York: Norton.

Sezer, Ö. (2005). İlkëğretim 1. kademe Türkşe ders kitaplarnda değerlerin incelenmesi. Yüksek lisans tezi, Marmara Üniversitesi Eğitim Bilimleri Enstitüsü, İstanbul.

Spranger, E. (1928), Types of men. Translated by P. J. W. Pigors, Halle, East Germany: Max Niemeyer Verlag. Spranger, E. (2001). İnsan tipleri bir kişilik psikolojisi (A. Aydoğan, Çev.). İstanbul: İz.

Tanriöver, H. U. (2003). Ders kitaplarında cinsiyet ayrımcilı̆̆1. B. Cotuksöken, A., Erzan, A. Ve O. Silier (Ed.) Ders kitaplarnda insan haklar: Tarama sonuclar (ss. 106-121). Nişantassl: Türkiye Ekonomik ve Toplumsal Tarih Vakfi.arih Vakfi Yaymlar.

Tillman, D. (2000). Living values activities for young adults living values an educational program. Deerfield Beach, Florida : Health Communications, Inc.

Turan, İ. (2010). Bazı bat1 ve türk çocuk klasiklerinde dini ve ahlaki değerler. Din bilimleri Akademik Arasstrma Dergisi, 10, (1), 171-194.

Tüfekçioğlu, H. (1997). Ders kitapları üzerine yapılmıș iki çalıșma ve yetișkinlere okuma yazma öğreten iki kitap hakkında inceleme. İstanbul: Sosyoloji Dergisi, (4).

Türk Dil Kurumu (2018). Genel Türkçe sözlük. Web: http://www.tdk. gov.tr/index.php?option= com_ gts\&arama $=$ gts\&guid=TDK.GTS.52a049fcce7fc1.19820794 adresinden 14.04 .2018 tarihinde alınmıştır.

Varol, Ç. (2013). Sosyal bilgiler derslerindeki değerler eğitimi uygulamalarna ilişkin öğretmen görüsleri. Yüksek lisans tezi, Gazi Üniversitesi Eğitim Bilimleri Enstitüsü, Ankara.

Veugelers, W. \& Vedder P. (2003). Values in teaching. Teachers and Teaching: theory and practice, 9, 377-389.

Yazıc1, K.(2006). Değerler eğitimine genel bir bakış.Türklük Bilimi Arastırmalar, 19 (19), 499.

Yıldırım, A. \& Șimşek, H. (2011). Sosyal bilimlerde nitel araştırma yöntemleri (8.baskı). Ankara: Seçkin Yayıncılık.

Yin, R. K. (2011). Qualitative research from start to finish. New York: Guilford Press.

\section{İncelenen ders kitapları}

Bilen,O. (2017). Ortaokul matematik 7 ders kitabı. Gizem Yayınc1lı, Ankara.

Cirıtıc1, H., Gönen, İ, Kavas, D. vd. (2017). Ortaokul matematik ders kitabı 5. Milli Eğitim Bakanlı̆̆1 Ders Kitaplar1, İstanbul.

Güven, D. (2017). Ortaokul 6 matematik ders kitabı. Mega Yayıncılık, Ankara.

Üstündağ Pektaş,Y. (2017). Ortaokul matematik 8. simf ders kitabı. Öğün Yayınları, Ankara. 